\title{
九州地域における未利用エネルギー活用に関する研究 A STUDY ON UTILIZATION OF UNUSED ENERGY IN KYUSHU
}

\author{
依田浩敏*, 北山広樹**, 片山忠久***, 西田 勝**** \\ Hirotoshi YODA, Hiroki KITAYAMA, Tadahisa KATAYAMA \\ and Masaru NISHIDA
}

\begin{abstract}
Annual thermal demands for heating and cooling on built-up and redevelopment districts scattered on leading cities in Kyushu are estimated based on floor area of building use, further, some suitable districts for District Heating and Cooling (DHC) are picked up.

Possible area in and around the cities for utilization of unused energy are selected by concerned with its heat demands characteristics and unused energy distribution, further the quantity of usable energy sources are calculated on the possible area.

The feasibility of using unused energy in the suitable districts are discussed and its effects of energy saving and anti-pollution are made clear comparing DHC system including unused energy sources with unit air conditioning system.
\end{abstract}

\section{Keywords: Unused energy, District heating and cooling, Leading cities in Kyushu, Heat demand, Energy conservation, Reduction in air pollution 末利用エネルギ，地域冷暖房，九州主要都市，熱需要量，省エネルギー，大気污染物質排出削減}

\section{1. はじめに}

地球環境問題への対応が求められる中、増加する民生用エネルギ 一需要の現状から都市における冷暖房設備は、都市環境や都市エネ ルギー面から見ても効率的に行うことが要求される。そのひとつと して地域冷暖房への期待が大きい。従来の建物個別による冷暖房方 式に比一熱源設備を集中化し、効率的な運用管理ができることから 需要者側の機城設備スペースが削减され安全性も向上する上、その スケールメリットを生かした丈夫により熱負荷の平準化を可能とす る。さらに、未利用エネルギーと総称される、都市の中の排熱や自 然のエネルギーをその熱源として活用すれば、より大きな効果が期 待される。

本研究は、このような末利用エネルギーを活用した地域冷暖房の 導入可能性について九州地域を対象に検討寸るものである。

都市計画上の法定容積率 $400 \%$ 以上の地区が存在し、人口 10 万 人以上の九州主要都市を対象とする。これら都市内の既成市街地や 開発地区の建物床面積データを収集し、それらより求められる熱需 要量や熱負荷密度加ら、将来的に地域冷暖房導入可能な地区 (以下、 高密度地区）の抽出を行う。さらに、その周辺に存在する未利用エ ネルギーの賦存量を求め、地理的条件加末利用エネルギー活用可 能地区を選定する。最終的に、これらの地区で未利用エネルギーの
活用効果として、省エネルギ一効果と環境負荷低减効果を試算する。 未利用エネルギーは、主に人間活動により発生するごみや下水を 処理する際の焼却排熱や温度差エネルギー、または排熱が集中して 発生する地下鉄・地下街・変電所、自然環境にある河川や海水等さ まざまである。地下鉄・地下街・変電所での排熱量は小さく、その 熱回収の難しさや利用効率とコストパフォーマンス等種々の面から 活用が容易ではない。無限な賦存量が期待される海水利用の場合は、 海岸沿いの特定された地域に限定されるなどの利用要因が影響する。 したがって、本研究では利用効率が高く賦存する熱量が期待される 清掃工場と下水処理場および一級河川を検討の対象とする。 解析は平成 6 年度の資料を用いて行った。

\section{2. 九州主要都市における熱需要の推計 \\ 2-1 既成市街地における等需要の現状と高密度地区の抽出}

建物床面積デ一夕の整備状況を把握するために、各都市の担当部 局ヘアンケートによる事前調查りを行った。その結果、独自に建物 床面積デー夕を整備しているところは少なく、ほとんどが課税台帳 などに記載される建物面積資料に準ずるものであった。記載方法か ら見れば、その建物床面積データは、大別して(1)市全体の建物床面 積が町丁目別に記載される場合と、(2)市全体での建物床面積のみが

\footnotetext{
* 近畿大学九州工学部建築学科 助教授. 工博

** 九州産業大学工学部建築学科 講師 $\cdot$ 工博

*** 九州大学大学院総合理工学研究科 環境エネルギー工学専攻 教授・工博

**** 九州産業大学工学部建築学科 教授. 工博
}

Assoc. Prof., Dept. of Architecture, Faculty of Engineering in Kyushu, Kinki Univ., Dr. Eng.

Lecturer, Dept. of Architecture, Faculty of Engineering, Kyushu Sangyo Univ., Dr. Eng.

Prof., Dept. of Energy and Environmental Engineering Sciences, Kyushu Univ., Dr. Eng.

Prof., Dept. of Architecture, Faculty of Engineering, Kyushu Sangyo Univ., Dr. Eng. 
記載されている場合、の2つである。

各都市の建物床面積デー夕の整備内容、およびこれらのデー夕を 用いて建物床面積を想定寸る方法をまとめて表 1 に示寸。(1)の場合 は、建物用途の数により 3 分類し、それぞれの方法により処理して、 建物用途別延床面積の想定を行った。(2)の場合は、市域全体あるい は商業地域での值しか推計できない。そこで、少なくとも法定容積 率ごとの建物延床面積を想定寸るために、(2)場合の都市と都市規 模や都市機能が類似している考えられる長崎市と熊本市の建物用途 別延床面積を用いて、法定容積率 $400 \%$ 地域と $500 \%$ 以上地域の、単 位面積あたりの建物用途別延床面積の構成比率（以下、グロス容積 率）を算出し洼》、各都市の法定容積率ごとの地域面積に乗じて建 物用途别延床面積の想定を行った。

(1)の場合は、想定した建物用途別延床面積に熱需要原単位注りを 乗じて熱需要と熱負荷密度 (熱需要を地区面積て除した值)を町丁 目単位で算出し、熱負荷密度が $4.0 \mathrm{TJ} / \mathrm{ha}$ •年(約 $1.0 \mathrm{Tcal} / \mathrm{ha}$ ·年)以 上て地区面積が $5.0 \mathrm{ha}$ 以上の地区を高密度地区とし、これらが複数

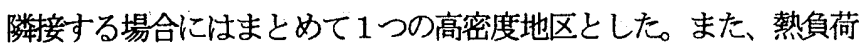
密度が $2.0 \mathrm{TJ} / \mathrm{ha}$ ・年 (約 $0.5 \mathrm{Tcal} / \mathrm{ha} \cdot$ 年) 以上 $4.0 \mathrm{TJ} / \mathrm{ha}$. 年 (約. 1. 0Tcal/ha·年)未満地区で、地区面積が $5.0 \mathrm{ha}$ 以下の地区について は、同隣接寸る地区とあわせて $4.0 \mathrm{TJ} / \mathrm{ha}$ ·年(約 $1.0 \mathrm{Tcal} / \mathrm{ha}$ ·年) 以 上で地区面積が $5.0 \mathrm{ha}$ 以上であれ代あるわせた地区を 1 つの高密度 地区とした。(2)の場合は、特定な地区の熱需要を推計するのは困難 であるため、法定容積率 500\%以上地区を高密度地区とした。

\section{2-2 開発計画地区における熱需要予測と高密度地区の抽出}

新開発・再開発地区に対して、面積や建物用途別延床面積が具体 的に特定できる地区については熱需要の推計が容易であるが、開発 計画地区面積や土地利用面積のみしか把握できない地区ついては、 熱需要や熱負荷密度の推計は難しい。

そこで、地区面積が1. 0ha以上で総延床面積が25,000m²以の、 計画中ならびて既に完了した、建物用途別延床面積の把握できる開 発プロジェクト9を5つのタイプに分類し、それぞれのタイイプごと
にグロス容積率を求めた。のグロス容積率の設定值を表 2 に示寸。 開発地区面積や土地利用面積のみしか把握できない地区については、 開発計画内容に最も近いと考えられるタイプを表中から選択し、そ のタイプに応じたグロス容積率を地区面積に乗じて、建物用途別延 床面積を想定した。

開発計画地区においても、熱負荷密度が $4.0 \mathrm{TJ} / \mathrm{ha} \cdot$ 年 (約 1. 0Tcal/ha·年)以上である開発地区を高密度地区とするが、広域で かつ高密度な地区が地域冷暖房の効率面からみて有效であると考え られるため、地区面積が 1.0ha 以上で開発計画地区の総延床面積が $25,000 \mathrm{~m}^{2}$ 以上のものを高密度地区とした。

\section{2-3 主要都市における熱需要と高密度地区}

九州主要都市の年間熱需要量と、既成市街地およひ開発計画地区 に扔ける高密度地区の年間熱需要量を表 3 に示寸。

年間熱需要量は福岡市が $32297.6 \mathrm{TJ} /$ 年と最も大きく、次いで北 九州市、熊本市の順で、これらの都市の熱需要量は概子都市人口に 比例する。既成市街地に拉ける高密度地区は 37 地区であり、主要 都市全体の熱需要が $16240.4 \mathrm{TJ} /$ 年に対して、福岡市は $60.9 \%$ を占 める。また、開発計画地区における高密度地区は 30 地区であり、 主要都市全体の熱需要が $10483.8 \mathrm{TJ} /$ 年に対して、福岡市が $3329.9 \mathrm{TJ} /$ 年、久留米市が $3147.3 \mathrm{TJ} /$ 年と大きい值となっている。

\section{3. 九州主要都市の未利用エネルギ賦存量と活用可能性}

\section{3-1 未利用エネルギー熟源の現状}

九州主要都市に存在する清掃工場の焼却排熱と下水処理場の処 理水、九州地域の一級河川を対象に、それらの分布と賦存量の算 定を行った。賦存量算定にあたっては、アンケート調查”により入 手した各都市に推ける清掃工場、下水処理場の設備概要や月別処 理実績値等を、また、河川の流量データ等については九州地方建 設局より入手した一級河川の流量観測所におけるデータを利用し た。

表 1 ，建物床面積データの概要と床面積想定の方法

\begin{tabular}{|c|c|c|c|}
\hline & 床面積の記載区分 & 処理方法 & 該当する都市名 \\
\hline \multirow[t]{3}{*}{$\begin{array}{l}\text { (1)町丁目ごとに床面積が } \\
\text { わかる場合 }\end{array}$} & $\begin{array}{c}A \\
\text { 建物用途が細かく分類される }\end{array}$ & 建物用途を集約する & 福岡市·長崎市·熊本市 \\
\hline & $\begin{array}{c}\mathrm{B} \\
\text { 建物用途が大まか分類される }\end{array}$ & 建物用途をさらに細かく分類する & 佐賀市·大牟田市 \\
\hline & 建物用途別に分頪されていない & $\begin{array}{l}\begin{array}{l}\text { 福岡市の建物用途別構成此 } \\
\text { 類する を用いて分 }\end{array} \\
\end{array}$ & 北九州市·久留米市 \\
\hline $\begin{array}{l}\text { (2市全域での床面積のみ } \\
\text { わかる場合 }\end{array}$ & & $\begin{array}{l}\text { 長崎市と態本市から想定した建物用途別 } \\
\text { 床面積比率を用いて床面積を想定する }\end{array}$ & 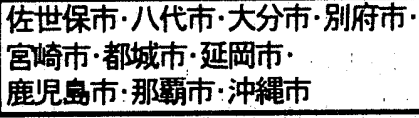 \\
\hline
\end{tabular}

表2 開発プロジェクトの分類とグロス容積率

\begin{tabular}{|c|c|c|c|c|c|c|}
\hline & 開発プロジェクトの分類とその特徵 & \multicolumn{5}{|c|}{ グロス容積率(\%) } \\
\hline 分類 & タイプの摘要 & 住宅 & 業務 & 商業 & 宿泊 & 娛楽 \\
\hline タイプ1 & 集合住宅·商業中心で住宅の延床面積が60\%以上を占める & 9.9 & 0.3 & 0.1 & 0.0 & 0.0 \\
\hline タイプ2 & 業務·商業中心で業務·商業の延床面積が80\%以上を占める & 4. 1 & 58.6 & 57.1 & 0.0 & 0.0 \\
\hline タイプ3 & 業務中心で業務の延床面積が80\%以上を占める & 0.0 & 170.1 & 4. 7 & 0.0 & 0.0 \\
\hline タイプ4 & 商業中心で商業の延床面積が80\%以上を占める & 0.0 & 0.0 & 109.2 & 1.2 & 0.0 \\
\hline & 混在しており他のタイプこ当てはまらない & 11.9 & 34.4 & 26.8 & 29.0 & 3. 9 \\
\hline
\end{tabular}


表3 九州主要都市における年間熟需要量の推計値と高密度地区の熱需要

\begin{tabular}{|c|c|c|c|c|c|c|c|c|c|c|c|c|}
\hline \multirow{3}{*}{ 都市名 } & \multirow{2}{*}{\multicolumn{2}{|c|}{$\frac{\text { 市域全体 }}{\text { 熱需要 }(\mathrm{TJ} / \text { 年) }}$}} & \multicolumn{5}{|c|}{ 既成市街地 } & \multicolumn{5}{|c|}{ 開発計画地区 } \\
\hline & & & \multirow{2}{*}{$\begin{array}{l}\text { 地 } \\
\text { 区 } \\
\text { 数 }\end{array}$} & \multirow{2}{*}{$\begin{array}{l}\text { 地区 } \\
\text { 面積 } \\
\text { (ha) }\end{array}$} & \multicolumn{3}{|c|}{ 熱需要 $(\mathrm{TJ} /$ 年) } & \multirow{2}{*}{$\begin{array}{l}\text { 地 } \\
\text { 区 } \\
\text { 数 }\end{array}$} & \multirow{2}{*}{$\begin{array}{l}\text { 地区 } \\
\text { 面積 } \\
\text { (ha) }\end{array}$} & \multicolumn{3}{|c|}{ 熱需要 (TJ/年) } \\
\hline & 冷熟 & 温鄚 & & & 冷熟 & 温熱 & 合計 & & & 冷熱 & 温熱 & 合計 \\
\hline 福岡市 & 7920.9 & 24376.7 & 14 & 1432.4 & 3086.2 & 6809.7 & 9895.9 & 8 & 470.7 & 1572. 6 & 1757.3 & 3329.9 \\
\hline 北九州市 & 3991.6 & 14335.3 & 2 & 119.3 & 143.6 & 536.8 & 680.4 & 3 & 55.7 & 189. 3 & 175.4 & 364.7 \\
\hline 久留米市 & 1918. 2 & 5253. 0 & 1 & 73. 7 & 358.4 & 96.3 & 454.7 & 3 & 322.0 & 1066. 4 & 2080.9 & 3147.3 \\
\hline 大牟田市 & 482. 3 & 2665. 2 & 1 & 11.4 & 16.7 & 33.1 & 49.8 & 1 & 18. 1 & 59.5 & 57.4 & 116.9 \\
\hline 佐贺市 & 831.7 & 2780.1 & 1 & 33. 6 & 56.9 & 77.9 & 134.8 & 0 & & & & \\
\hline 長崎市 & 1597. 8 & 7005.3 & 6 & 168.0 & 358.8 & 868.8 & 1227. 6 & 3 & 26.5 & 73. 3 & 139.4 & 212.7 \\
\hline 佐世保市 & 1090.2 & 1708.7 & 1 & 51.0 & 134.0 & 271.7 & 405.7 & 1 & 74.0 & 242. 8 & 234.1 & 476. 9 \\
\hline 熊本市 & 1519.0 & 7914. 2 & 2 & 84.2 & 261.7 & 403. 6 & 665.3 & 2 & 19. 8 & 64.9 & 62.4 & 127.3 \\
\hline 八代市 & 420.3 & 750.7 & 1 & 15.0 & 39.4 & 80.0 & 119. 4 & 1 & 11.3 & 37.7 & 85.0 & 122. 7 \\
\hline 大分市 & 2188.3 & 6637.7 & 1 & 61.0 & 160.4 & 324.9 & 485. 3 & 1 & 49.7 & 165.0 & 374. 3 & 539.3 \\
\hline 別府市 & 430.2 & 1602. 2 & 1 & 34.0 & 89.2 & 180.0 & 269. 2 & 0 & & & & \\
\hline 宮崎市 & 1232. 3 & 3541.8 & 1 & 45.0 & 118.5 & 239.5 & 358.0 & 2 & 115.5 & 379.3 & 365.1 & 744.4 \\
\hline 都城市 & 455.9 & 1635.7 & 1 & 70.0 & 183. 8 & 372. 6 & 556.4 & 1 & 12. 9 & 42. 7 & 97.1 & 139.8 \\
\hline 延岡市 & 330.0 & 1472. 6 & 1 & 24.0 & 63.2 & 127.7 & 190.9 & 0 & & & & \\
\hline 鹿児禹市 & 1548. 9 & 5656. 9 & 2 & 81.0 & 215.6 & 431.3 & 646.9 & 2 & 20.2 & 67.0 & 138. 2 & 205.2 \\
\hline 那覇市 & 953.9 & 1634.8 & 1 & 16.0 & 52.8 & 47. 3 & 100.1 & 1 & 2. 5 & 18. 8 & 7.5 & 26. 3 \\
\hline 沖縄市 & 789.5 & 1115.6 & 0 & & & & & 1 & 104.5 & 433.8 & 496.6 & 930.4 \\
\hline 計 & 27701.1 & 90086.6 & 37 & 2319.6 & 5339.2 & 10901.2 & 16240.4 & 30 & 1303.4 & 4413.1 & 6070.7 & 10483.8 \\
\hline
\end{tabular}

九州主要都市における研究対象とした末利用エネルギ一熱源は、 清掃工場が 28 施設、下水処理場が 50 施設である。また、九州地 域の一級河川は 19 河川であり、そのうち九州主要都市内に流れる 河川は 11 河川である。

末利用エネルギー活用の現状は、清掃工場 28 施設のうち 25 施 設（約 90\%）で焼却排熱を場内利用しており、その利用用途は、 給湯が $43 \%$ と最も多く、次いで場内空調で $31 \%$ 、発電の $15 \%$ とな っている。下水の利用については、一部中水利用が行われている ものの熱利用している施設はみられない。河川についても同様に 熱利用はされていない。

また、未利用エネルギー源の熱的特性は、清掃工場における可 然物の低位発熱量の実績值は、5460MJ/t（約 $1305 \mathrm{Mcal} / \mathrm{t}$ ) から $10593 \mathrm{MJ} / \mathrm{t}$ (約 $2530 \mathrm{Mcal} / \mathrm{t}$ ）となっており、都市の規模や機能によ り排出されるごみの組成により差が見られる。

下水処理水および河川の水温と、気温との関倸は、冬季におい て下水処理水温は気温よりも $10^{\circ} \mathrm{C}$ 前後、河川水温は気温よりも $5^{\circ} \mathrm{C}$ 程度高くなっており、夏季においては下水処理水温と河川ともに 気温より $3 \sim 4^{\circ} \mathrm{C}$ 程度低くなっている。

\section{3-2 未利用エネルギ一賦存量}

各末利用エネルギ一熱源の潜在的な熱量から実際に空調機器の 熱媒（清掃工場は蒸気、下水処理場・河川は椧温水）として利用 が可能な熱量を賦存量として定義し、算定式 ${ }^{14.15)}$ を表4に示す。

清掃工場と下水処理場については、月別害績值をもとに月別賦 存量を算出し、これらを年間で積算して年間賦存量を求めた。河 川については、各流量観測所の時間あたりの流量から月別賦存量 を算出し、これを積算して年間賦存量を求めた。清掃工場の賦存 量算定では、ごみ焼却排熱の場内利用分を考慮せず処理実績から 求められるすべての熱量を賦存量と考えた。また、賦存量算定に おけるごみ焼却時の低位発熱量は、調查により得られた各清掃工 場での実績值を用いた。この低位発熱原単位にごみ焼却量を乗じ、
表 4 未利用エネルギ 賦存量算定式

\begin{tabular}{|c|c|c|}
\hline 施設種別 & 賦存量 $Q(T \mathrm{~J} /$ 年) & 記号の説明 \\
\hline 涌㛿工場 & $R_{d} \times \sigma_{d} \times \eta_{B}$ & $\begin{array}{l}R_{d}: \text { 年間焼却ごみ量 }(t / \text { 年) } \\
\sigma_{d}: \text { 低位発熱量 }(M J / t) \\
\eta_{\mathrm{B}}: \text { 熟回収ボイラ効率 } 0.8\end{array}$ \\
\hline 下水処理場 & $R_{w} \times C_{p w} \times T$ & $\begin{array}{l}\mathrm{R}_{\mathrm{w}}: \text { 年間下水処理量 }\left(10^{3} \mathrm{~m}^{3} / \text { 年) }\right. \\
\mathrm{C}_{\mathrm{PW}} \text { : 水の定圧比熟 }\left(\mathrm{MJ} / 10^{3} \cdot{ }^{\circ} \mathrm{C}\right)\end{array}$ \\
\hline 河川 & $V_{w} \times 0.05 G_{w w} \times T$ & $\begin{array}{l}\mathrm{T}: \text { 利用温度差 } \quad 5\left({ }^{\circ} \mathrm{C}\right) \\
\mathrm{V}_{\mathrm{w}}: \text { 年間流量 }\left(\mathrm{m}^{3} / \text { 年 }\right)\end{array}$ \\
\hline
\end{tabular}

燒却排熱を求め、その熱を熱回収ボイラーで回収する際に発生す る蒸気の熱量を賦存量とした。下水処理水と河川水は、利用温度 差を $\left.5^{\circ} \mathrm{C}^{16}\right)$ に処理実績量・流量を乗じて賦存量を求めた。なお、河 川では利用可能な流量を月別流量の $5 \%$ として算定した。

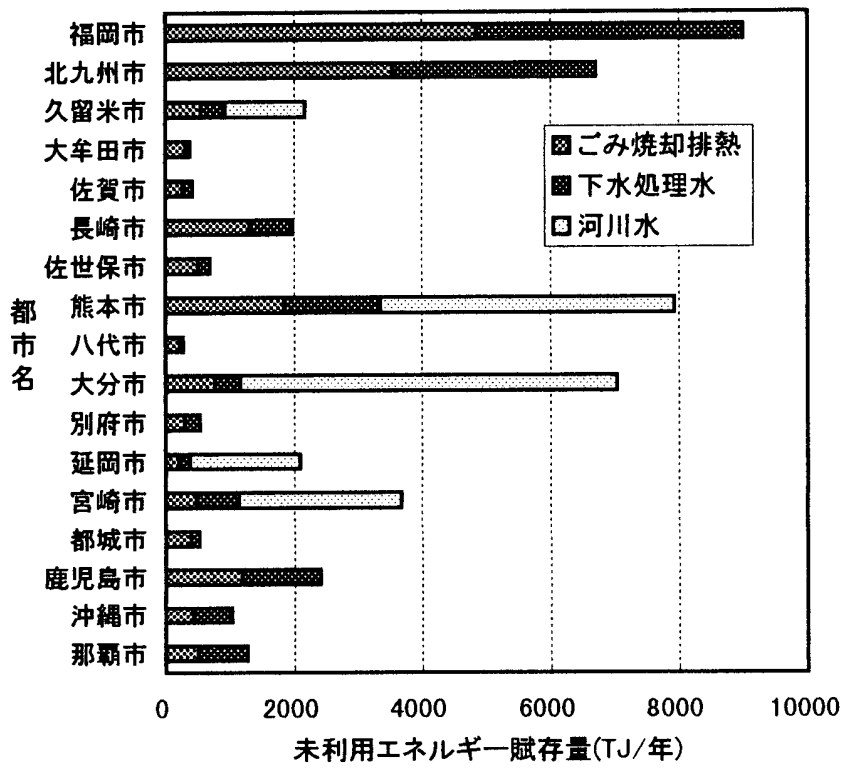

図 1 九州主要都市における未利用エネルギ一賦存量 
九州主要都市における未利用エネルギー賦存量の算定結果を、 年間賦存量として各都市ごとに図 1 に示す。100 万人都市である福 岡市・北九州市は他の都市と比較し、清掃工場や下水処理場の有 する賦存量が大きくなることがわかる。また、久留米市・熊本市・ 大分市・八代市・宮崎市・延岡市の 6 都市に一級河川があり、特 に熊本市は 3 河川が市内を流れているため、河川水の賦存量が大 きくなっている。

\section{3-3 未利用エネルギー活用可能地区と活用可能第量}

末利用エネルギ一活用可能地区は、熱媒搬送の経済性や地理的条 件を考慮し、清掃工場から $2 \mathrm{~km}$ 以内、下水処理場加 $5 \mathrm{~km}$ 以内、 河川に接している高密度地区とした。

各都市での単純な地理的用件のみで末利用エネルギーの活用可能 性を評価すれば、福岡市では下水処理場や清掃工場が活用可能な熱 源として存在し、北九州市では、高密度地区が線状で広域にわたる ため近接する処理施設が多く散在する。特に、小倉北区、若松・黒 崎地区ではそれらの活用可能性も高いものと考えられる。西鉄久留 米駅を中心に高密度地区が広がる久留米市では、都市処理施設との 距離が遠く、また、大牟田市では清掃工場が高密度地区に隣接する。 福岡県以外の都市をみれば、長崎市、熊本市、大分市、延岡市など では高密度地区に隣接する処理施設等も多く存在する。特に、大分 市と熊本市の場合には、一級河川に接することからその活用も考え られる。また、八代市や都城市、鹿照島市では比較的近隣に清掃工 場や下水処理場が立地する。以上より、九州主要都市の中で高密 度地区として抽出された 67 地区のうち、熱源との地理的条件から みた末利用エネルギーの活用可能地区は 19 地区となる。この 19 地 区を対象に末利用エネルギーの活用可能熱量を推計した。

末利用エネルギ一活用可能地区において、その熱需要特性と未利 用エネルギーの活用可能な熱量との関係を把握するために、まず、 各地区ごとに累積需要曲線を作成した。年間原単位を構成する月別 熱需要原単位およひ都市ごとの日平均気温の平年值 わをとに日 別熱需要量を求め、これを時刻別変動係数 ${ }^{18)}$ により 1 日単位の熱 需要パターンに振り分け時刻別熱需要量を算出した。これを熱需要 の高い順に並べ、年間の需要パターンを累積需要曲線 ${ }^{18)}$ として作 成した。また、各種の未利用エネルギ一源の年間賦存量を単純に 365 日 24 時間で除せば、年間を通して常に一定量を供給できると考え た場合の時刻別活用可能な熱量を得る。活用可能地区における累積 需要曲線と末利用エネルギーの賦存量の関係から、地区特性と末利 用エネルギーの活用可能性について概ね推測できる。

次に、未利用エネルギ一賦存量がその活用可能地区の熱需要に占 める定量的熱量の推計について考える。熱源として未利用エネルギ 一を活用する地域冷暖房は、蓄熱などのサブシステムを一切考えず、 単純に熱を一定活用する方式を想定し、未利用な熱源からどれだけ の熱を活用できるかを月別に温・冷熱別に求め、これを活用可能熱 量として推計した。高温排熱である清掃工場の熱源がもつ賦存量は、 蒸気としてこれを直接活用できるものとした。また、下水処理水や 河川水の場合には、ヒートポンフによる二次的活用を考え、利用寸 る月ごとの水温データをもとに月別に水熱源ヒートポンプの成績係 数を温熱・冷熱ごとに求め ${ }^{19)}$ 、この成績係数と賦存量から利用可 能な熱量を算定し、これを月別熱需要に対して活用するものとした。
末利用エネルギー賦存量が対象となる地区の温・冷熱需要を上回る 場合には、余㮃する熱量があってもそれ活用せずに捨てることに なる。逆に、賦存量が活用可能地区での温・冷熱需要の両方を下回 る場合には、月別の温熱需要量と冷熱需要量のうち大きい方の需要 に対して優先的に熱を活用するものとした。さらに、低温排熱の温 熱を供給する場合は、ヒートポンプの各月の温・冷熱成績俰数より 月ごとの投入電力量を求め、その熱量を加えて活用可能熱量として 求めた。

末利用エネルギーの活用範用内に複数の対象地区がある場合には、 最も年間熱需要量が大きな地区での活用を優先し、その他の地区で の活用を考えず余剩分の熱は棄てるものとした。また、活用できる 末利用エネルギーが複数ある場合、高温排熱を優先的に熱需要の高 い地区で活用し、不足分については別の未利用熱源の活用により補 うものとするが、低温排熱の活用は下水処理場を優先させた。

この未利用エネルギ一の活用が可能な19地区において、各都市ご とにその年間の活用可能熱量を合計し、九州主要都市における開発 地区を含めた都市全体での年間熱需要に対する割合を図 2 に示す。 都市別にみれば、熱需要の高密な地区が面的にも広域な福岡市では 市域全体の $11.7 \%$ に相当する熱需要を賄える未利用エネルギーが存 在し、また、九州内でも中小の都市の中でも高密度地区が比較的狭 い地域に集中し、その周辺に活用可能な未利用エネルギーが存在す る都市では、末利用エネルギ一の割恰も10\%程度と大きくなる。し かし、全体的にみれば福岡市を除く主要都市の中でも、比䡈的人口 が多い都市での未利用エネルギーの活用可能な割合は、都市全体の 熱需要に対して数\%程度である。

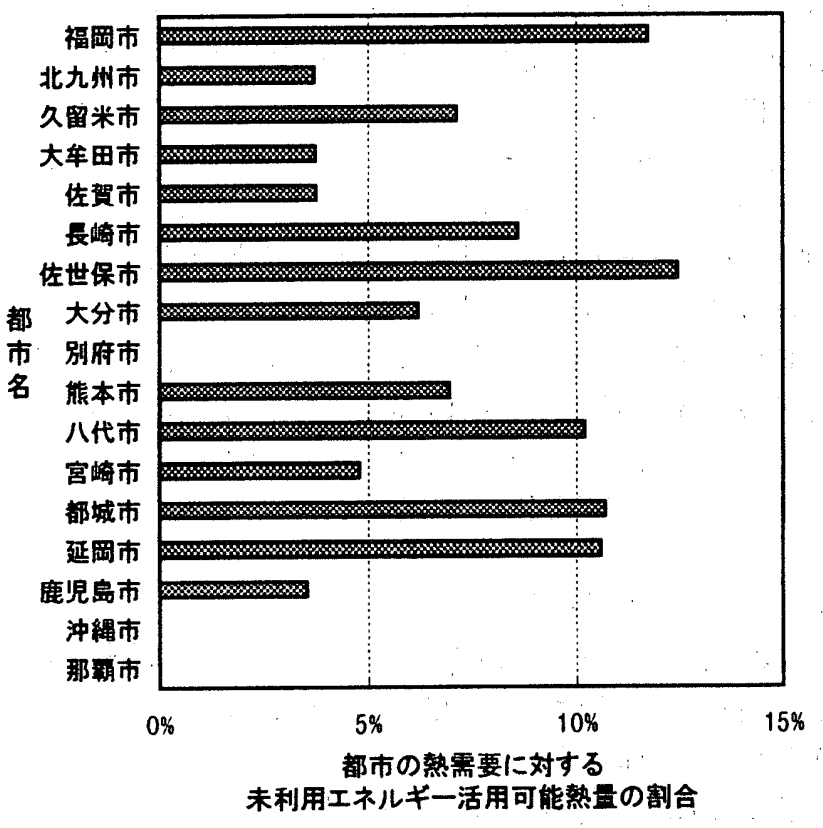

图2 九州主要都市の全欮需要に対する未利用エネルギー活用可能 熟量の割合

これらの結果を九州主要都市全体でまとめたものを表5に示す。 九州主要都市全体での熱需要量を椧熱および昷熱に分類し、さらに 高密度地区でのそれらの值とともに、未利用エネルギーの活用可能 熱量を示している。九州主要都市全体での未利用エネルギーによる 
活用可能熱量は、椧熱で2904. 9TJ/年 (693.8Tcal/年)、温熱で $5634.4 \mathrm{TJ} /$ 年 $(1345.7 \mathrm{Tcal} /$ 年) となる。これらの值は主要都市全域 での熱需要量に対してそれぞれ10.5\%、6.3\%に相当し、高密度地 区での值は、それぞれ $29.4 \% 、 32.8 \%$ に相当する。熱需要量全体か らみれば、九州主要都市での未利用エネルギ一の供給可能熱量が占 める割合は7.2\%、高密度地区での総熱需要量に対するその值は $31.5 \%$ となる。高密度地区での年間熱需要に対する活用可能熱量の 割合は、将来的にも熱需要が集中寸る地区での活用のみを考慮した ため大きな值となる。

\section{3-4 活用可能地区での省エネルギ一効果と環境負荷低隇効果}

抽出された未利用エネルギー活用可能地区における具体的な活用 効果として、未利用エネルギーを活用した地域泠暖房システムを導 入した場合の省エネルギ一効果およひ環境負荷低減効果の試算を行 った。

省エネルギー効果は、個別空調方式で投入される一次エネルギー 量から末利用エネルギ一を活用した地域冷暖房方式において投入さ れる一次エネルギー量を差し引き、この投入一次エネルギー削減量 を省エネルギー効果とした。

個別空調方式では、需要側が建物ごとに個別で泠暖房装置を設置 するものとし、電力、ガス、重油を投入エネルギーとして設定した。 未利用エネルギーを活用した地域冷暖房方式では、電力による冷暖 房には空気熱源ヒートポンプを用い、ガスと重油による椧房では苲 気吸収冷涷機、暖房にはボイラを用いるものとした。ごみ焼却排熱 を活用する場合には、蒸気を熱媒として冷暖房機器に投入するため 機器の動力エネルギーは考えないものとし、従来投入されていた一 次エネルギーがすべて削减されるものとした。また、下水処理水と 河川水を活用する場合には、水熱源ヒートポンプに投入される電力 を投入一次エネルギ一量とした。未利用エネルギー活用可能地区に おける熱需要量が、未利用エネルギ一の供給可能な熱量よりも大き な場合には、地域冷暖房での補助システムを導入して、その不足分 の熱量を補うものとした。この際の投入エネルギーとしては、電気 とガスを使用した。ここで設定される地域冷暖房システムにおける
投入一次エネルギー量は、末利用エネルギーを活用する場合の水熱 源ヒートポンプの動力である電力と、未利用エネルギーだけでは不 足する熱需要を補うための補助システムにおける投入エネルギーで あるガス・電気をそれぞれ一次エネルギー換算した值とした。電力 の一次エネルギー換算值は $1 \mathrm{kWh}=9420.8 \mathrm{~kJ}(2250 \mathrm{kcal})$ として計算 した。

それぞれの設定条件に基づき、冷暖房機器における投入エネルギ 一の消費構成注 3 と各泠暖房機器の効率と能力注 4) とを考慮し、未利 用エネルギー活用可能地区の熱需要に対して必要な投入一次エネル ギー量を求めた。

また、未利用エネルギ一活用による環境負荷低減効果は、投入一 次エネルギー削減量に大気污染物質排出原単位注 5) 莱じることに より炭酸ガス $\left(\mathrm{CO}_{2}\right)$ ・硫黄酸化物 $\left(\mathrm{SO}_{x}\right) \cdot$ 窒素酸化物 $\left(\mathrm{NO}_{x}\right)$ の 3 種類の大気污染排出量を求め、個別空調方式と末利用エネルギーを 活用した地域冷暖房方式との差を、環境負荷低減効果とした。

省エネルギ一効果およひ環境負荷低減効果をまとめたものが表 5 である。末利用エネルギ一活用による投入一次エネルギー削減率が $39.2 \%$ 、環境負荷低減効果としての大気污染物質排出削減率が約 39.4〜87. 9\%という効果がみられる。

また、未利用エネルギ一別にみれはば、焼却排熱を活用した場合の 効果は高く、投入一次エネルギ一削減率が平均で約 $80 \%$ 、下水処 理水を活用した場合では、焼却排熱に比べて低くなるがその值は平 均で約 $20 \%$ 程度である。河川水は、下水処理水や焼却排熱の活用 と併用したシステム設定が多く河川水による供給熱量は小さいが、 清掃工場や下水処理場よりも中心市街地に近いことから、種々の制 約はあるものの総合的な活用効果は高いものと考えられる。

以上の結果を、主要都市全体での熱需要に対して個別方式を仮定 すれば、末利用エネルギー活用によるエネルギ一削减量は、都市全 体の投入エネルギー量の約 7\%であり、大気污染物質排出削減量は 都市全体での排出量に対して $\mathrm{CO}_{2}$ や $\mathrm{NO}_{\mathrm{x}}$ で約 $0.7 \% 、 \mathrm{SO}_{\mathrm{x}}$ の場合で約 $1.2 \%$ となる。

表5 九州主要都市によける未利用エネルギ一活用可能熟量とその割合

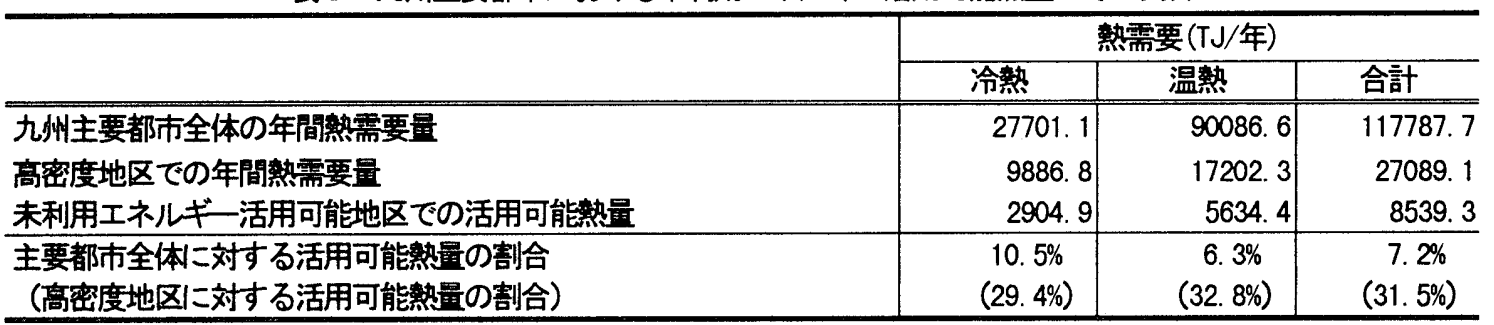

表6 省エネルギ一効果と環境負荷低減効果

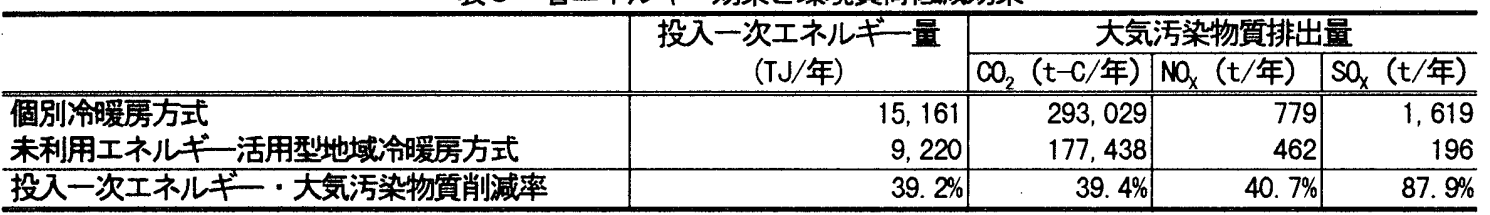




\section{4. まとめ}

法定容積率 $400 \%$ 以上地区が存在し、人口 10 万人以上の九州主 要 17 都市を対象に、未利用エネルギーを活用した地域冷暖房の導 入可能性について検討して得られた知見を以下に示寸。

未利用エネルギー活用可能地区ごとの年間熱需要量、熱源と施設 名、熱源から地区までの距離、賦存量、活用可能熱量、投入一次工 ネルギー削減量、大気污染物質削减率を表 7 にまとめる。

1) 建物用途別延床面積と熱需要原単位とから熱需要量を算出し、市 域全体において、冷熱が 27701.1TJ/年、温熱が 90086.6TJ/年であ った。

2)熱需要、熱負荷密度、地区面積などから、既成市街地 37 地区、 開発計画地区 30 地区の計 67 地区の高密度地区を抽出した。既成市 街地での総熱需要量は $16240.4 \mathrm{TJ} /$ 年であり、福岡市の值が他市に 比較して圧倒的に大きい。また、開発計画地区での総熱需要量は $10483.8 \mathrm{TJ} /$ 年であり、福岡・久留米両市の值が大きい。

3)高密度地区のうち、熱源との地理的条件からみた末利用エネルギ 一活用可能地区は 19 地区である。その活用可能熱量は、冷熱で 2904.9TJ/年、温熱で $5634.4 \mathrm{TJ} /$ 年となる。これらの值は主要都市 全域での熱需要量に対してそれぞれ、10.5\%，6.3\%に相当し、高 密度地区全域での熱需要量に対しては、それぞれ $29.4 \% 、 32.8 \%$ に相当する。

4)個別空調方式と比較した省エネルギー効果は、未利用エネルギー 活用による投入一次エネルギ一削减率が、都市全体て約 $7 \%$ \%あり、 名古屋市域の推計結果 $6 \%$ とほぼ同程度である。 エネルギー活用の対象となる地区だけで考えれば 39.2\%となり、 これも既往の文献 ${ }^{21)}$ に示される結果と同程度となる。
5) 個別空調方式と比較した環境負荷低减効果は、未利用エネルギー 活用による大気污染物質削减率が、都市全体での排出量に対して $\infty_{2}$ や $\mathrm{NO}_{x}$ で約 $0.7 \% 、 \mathrm{SO}_{x}$ の場合で約 $1.2 \%$ となる。また、末利用エネ ルギー活用の対象となる地区だけで考えれば、 $\mathrm{OO}_{2}$ が $39.4 \% 、 N \mathrm{~N}$ が $40.7 \% 、 \mathrm{SO}_{\mathrm{x}}$ が $87.9 \%$ となる。

末利用エネルギーの活用は、熱需要に対してのみ有効であること、 その熱需要密度の高い地域にのみ適用可能であることなどの制約条 件はあるものの、今後、二次側システム、運輸および生活などにお ける省エネルギー化とあわせ、都市エネルギーシステムとして積極 的に推進される可能性を持つ。

付記

本研究は、平成 7 年度 $~ 8$ 年度文部省科学研究費補助金基船研究 （A）「九州地域に扔ける都市・建築の未利用エネルギ一有效利用に 関寸る総合的研究」(課題番号 : 07305028、研究代表者 : 西田勝)、 平成 5 年度 $\sim 8$ 年度社団法人空気調和・衛生工学会九州支部「九州 地域の都市・建築エネルギー調查」研究委員会 (委員長 : 片山忠久) 平成 6 年度 8 年度社団法人日本地域冷暖房協会自主研究「プロジ エクト 2010 日本全国地域冷暖房導入可能性調查研究（研究代表 者 : 佐土原聡) の成果によるものである。

表7 未利用エネルギ一活用可能地区の熱需要と活用効果

\begin{tabular}{|c|c|c|c|c|c|c|c|c|c|c|c|}
\hline \multirow[t]{2}{*}{ 都市名 } & \multirow[t]{2}{*}{ 対象地区名 } & \multirow[t]{2}{*}{$\begin{array}{c}\text { 蟔需要量 } \\
(\mathrm{TJ} / \text { 年) }\end{array}$} & \multirow[t]{2}{*}{$\begin{array}{c}\text { 鿂源 } \\
\text { (施設名) }\end{array}$} & \multirow[t]{2}{*}{$\begin{array}{c}\text { 距離 } \\
(\mathrm{km})\end{array}$} & \multirow[t]{2}{*}{$\begin{array}{l}\text { 賦存量 } \\
\text { (TJ/年) }\end{array}$} & \multicolumn{2}{|c|}{$\begin{array}{c}\text { 活用可能熟量 } \\
\text { (TJ/年) }\end{array}$} & \multirow{2}{*}{$\begin{array}{c}\text { 投入一次 } \\
\text { エネルギ- } \\
\text { 削減量 } \\
(\mathrm{TJ} / \text { 年) }\end{array}$} & \multicolumn{3}{|c|}{$\begin{array}{c}\text { 大気污染物質削減率 } \\
(\%)\end{array}$} \\
\hline & & & & & & 冷熟 & 温熟 & & $\mathrm{CO}_{2}$ & $\mathrm{sO}_{\mathrm{x}}$ & $\mathrm{NO}_{\mathrm{X}}$ \\
\hline \multirow[t]{4}{*}{ 福岡市 } & 箱椅五丁目地区 & 69.5 & 下水㞦理水（東部） & 1.5 & 597. 3 & 9.2 & 72.4 & 26.8 & 31.2 & 82.4 & 38.9 \\
\hline & 福岡博多地区 & 3954.6 & 下水処理水（御笠川） & 1.8 & 1383.9 & 540.5 & 1014.5 & 661.5 & 21.0 & 84.0 & 22.8 \\
\hline & 福岡中央地区 & 4189.9 & 下水処理水（中部） & 1.8 & 1372.0 & 499.1 & 1047.2 & 677.9 & 21.2 & 84.3 & $\overline{22.6}$ \\
\hline & 姪浜地区 & 604.6 & ごみ焼却熟 (西部) & 3.7 & 1819.1 & 185.1 & 419.5 & 550.2 & 98.2 & 99.6 & 98.2 \\
\hline \multirow[t]{2}{*}{ 北九州市 } & 小會駅周辺地区 & 534.2 & ごみ焼却佺（日明） & 3.6 & 1344.6 & 112.6 & 421.2 & 473.5 & 97.3 & 99.5 & 97.4 \\
\hline & 黒䗁郘周辺地区 & 146.5 & ごみ暁却熱（皇后） & 2. 2 & 1163.3 & 30.6 & 115.5 & 133.6 & 100.0 & 100.0 & 100.0 \\
\hline 久留米市 & 広域都市拠点地区 & 1954.1 & ごみ暁却熟 (上津) & 4.8 & 554.2 & 191.3 & 320.3 & 521.7 & 38.8 & 90.9 & 37.1 \\
\hline 大牟田市 & 旭町東新町地区 & 116.8 & こみ暁却熟（新開） & 2.7 & 308.7 & 59.5 & 57.4 & 109.3 & 97.7 & 99.5 & $\overline{97.8}$ \\
\hline 佐賀市 & 中央本町地区 & 134.8 & こみ燒却愁（佐賀） & 5.0 & 259.9 & 56.9 & 78.3 & 122.7 & 96.8 & 99.4 & 96.7 \\
\hline \multirow[t]{2}{*}{ 長䗁市 } & \multirow[t]{2}{*}{ 長崎市内地区 } & \multirow[t]{2}{*}{751.6} & こみみ焼却熟（東工場） & 3.1 & 758.7 & \multirow[b]{2}{*}{ 237. 0} & \multirow[b]{2}{*}{503.2} & \multirow[b]{2}{*}{608.0} & \multirow[b]{2}{*}{ 84. 7} & \multirow[b]{2}{*}{95.7} & \multirow[b]{2}{*}{86.2} \\
\hline & & & 下水迈理水（中部） & 1.8 & 318.9 & & & & & & \\
\hline 佐世保市 & 佐世保駅周辺地区 & 476.9 & こみ焼去熱 (西部) & 2.0 & 397.1 & 142.4 & 206.0 & 348.8 & 43.6 & 92.0 & $\overline{42.1}$ \\
\hline \multirow[t]{2}{*}{ 能本市 } & 中心市内地区 & 582.8 & 河川水（白川－小皇橋） & 0.0 & 1819.2 & 248.3 & 363.0 & 207.3 & 22.5 & 74.5 & 31.3 \\
\hline & 熊本駅周辺地区 & 43.5 & こみ焼去知 (西部) & 4.7 & 933.3 & 22.2 & 21.4 & 41.9 & 100.0 & 100.0 & 100.0 \\
\hline 八代市 & 八代中央地区 & 119.3 & こみ暁却熟（八代） & 2.5 & 229.1 & 39.4 & 80.0 & 109.7 & 98.5 & 99.7 & 98.6 \\
\hline \multirow{2}{*}{ 大分市 } & 大分駅地区 & 485.2 & ごみ焼却熱（弁天） & 1.8 & 144.7 & \multirow[b]{2}{*}{161.2} & \multirow[b]{2}{*}{386.5} & \multirow[b]{2}{*}{172.1} & \multirow[b]{2}{*}{23.4} & \multirow[b]{2}{*}{ 76. 9} & \multirow[b]{2}{*}{ 32. 3} \\
\hline & & & 河川水 (大分川・広瀬橋) & 0.0 & 1565.1 & & & & & & \\
\hline 宮崎市 & 盘通り周辺地区 & 228.6 & ごみ焼却熱 (南部) & 4.9 & 479.3 & 32.0 & 112. 2 & 207.7 & 94.9 & 98.9 & 94.9 \\
\hline 都城市 & 都城駅地区 & 556.5 & こみみ焼却熟（都城） & 2.8 & 214.8 & 89.6 & 134.0 & 311.1 & 65.4 & 94.7 & 64.5 \\
\hline 延岡市 & 延岡中央地区 & 190.9 & ごみ暁却热 (延岡) & 2.5 & 394.8 & 63.2 & 127.7 & 177.5 & 100.0 & 100.0 & 100.0 \\
\hline 鹿坚酉市 & 鹿韭吾中心地区 & 511.2 & 下水処理水（錦江） & 1.9 & 236.6 & 100.5 & 154.1 & 109.3 & 23.9 & 83.6 & 26.3 \\
\hline
\end{tabular}


注

1) 法定容積率ごとの建物用途別グロス容積率設定值

\begin{tabular}{|c|c|c|c|c|c|c|c|}
\hline 法定容䅡率 & $\begin{array}{l}\text { 戸建 } \\
\text { 住宅 }\end{array}$ & $\begin{array}{l}\text { 集合 } \\
\text { 住宅 }\end{array}$ & $\begin{array}{l}\text { 業務 } \\
\text { 施設 }\end{array}$ & $\begin{array}{l}\text { 商業 } \\
\text { 施設 }\end{array}$ & $\begin{array}{l}\text { 宿泊 } \\
\text { 施設 }\end{array}$ & $\begin{array}{l}\text { 悞楽 } \\
\text { 施設 }\end{array}$ & $\begin{array}{l}\text { 医癔 } \\
\text { 施設 }\end{array}$ \\
\hline $400 \%$ & $14 \%$ & $32 \%$ & $25 \%$ & $31 \%$ & $7 \%$ & $3 \%$ & $2 \%$ \\
\hline $500 \%$ 以上 & $8 \%$ & $22 \%$ & $36 \%$ & $41 \%$ & $10 \%$ & $3 \%$ & $2 \%$ \\
\hline
\end{tabular}

2) 九州地域における熱需要原単位

\begin{tabular}{|c|c|c|c|}
\hline & 椧熱 & 暖房 & 給湯 \\
\hline 可建住宅 & $14.2(18.0)$ & $115.1(11.7)$ & $143.2(143.2)$ \\
\hline 集合住宅 ${ }^{2 D}$ & $20.5(25.5)$ & $124.4(12.6)$ & $224.0(224.0)$ \\
\hline 策務施没 & $261.3(326.6)$ & $236.1(23.4)$ & $37.3(37.3)$ \\
\hline 商業施設 & 305.7 (382. 3) & 140.3(14. 2) & 107. 6( 107.6$)$ \\
\hline 宿泊施設 & $271.7(339.6)$ & 495. 3 (49. 4) & $1296.3(1296.3)$ \\
\hline 肈楽施設 & $273.0(341.2)$ & $820.7(82.1)$ & $-(-)$ \\
\hline 医療施設 18 & $196.4(245.4)$ & $476.5(47.7)$ & $1007.4(1007.4)$ \\
\hline
\end{tabular}

沖縄地区については、社 日本地域冷暖房協会による地域補正倸数に基づき、 沖縄地区以外の九州地区原単位に対して、冷熱 1.25 倍、暖房 0.1 倍、給湯 1.0 倍とした。

\section{3) 冷暖房機器にお引ける投入エネルギーの消費構成}

文献 23)に基づき、個別空調システムにおいては、冷房では電気 $69.1 \%$ 、ガ ス $22.6 \%$ 、重油 $8.3 \%$ 、暖房では電気 $34.4 \%$ 、ガス $23.4 \%$ 、重油 $42.2 \%$ と した。また、未利用活用型地域冷暖房システムにおいては、椧熱・温熱とも にそれぞれ 50\%とした。

4) 冷暖房機器の効率と能力

空気熱源ヒートポンプ

温熱 : $y=-0.0007 x^{2}+0.0832 x+3.1097$ 冷熱 : $y=0.0036 x^{2}-0.3414 x+10.596$

水熱源ヒートポンプ

温熱 : $\mathrm{y}=0.0059 \mathrm{x}^{2}-0.0417 \mathrm{x}+3.4252$ 冷熱 : $\mathrm{y}=0.0033 \mathrm{x}^{2}-0.2539 \mathrm{x}+9.1742$

( $y:$ 成績係数 $\mathrm{x}:$ 気温)

蒸気吸収冷涷機、ボイラ効率 : 0.8

5) 大気污染物質排出原単位

\begin{tabular}{|c|c|c|c|}
\hline \multirow[t]{2}{*}{ 大気污染物質 } & \multirow[t]{2}{*}{ 発電所 } & \multicolumn{2}{|c|}{ ボイラ } \\
\hline & & 都市ガス & A重油 \\
\hline $\begin{array}{l}\mathrm{NO}_{\mathrm{x}}(\mathrm{kg} / \mathrm{TJ}) \\
\mathrm{SO}_{\mathrm{x}}(\mathrm{kg} / \mathrm{TJ}) \\
\mathrm{CO}_{2}(\mathrm{~kg}-\mathrm{C} / \mathrm{TJ})\end{array}$ & $\begin{array}{c}56.18^{24} \\
39.53^{24} \\
0.24 \times 10^{525}\end{array}$ & $\begin{array}{c}40.77^{26} \\
2.60^{277} \\
0.135 \times 10^{5}\end{array}$ & $\begin{array}{c}53.4^{26} \\
219.82^{27} \\
0.189 \times 10^{5}\end{array}$ \\
\hline
\end{tabular}

\section{本論文に関連するおもな発表文献}

1) 朝比奈慶一ほか 4 名: 九州主要都市における就需要と未利用エ ネルギー賦存量調查一九州地域の未利用エネルギー有効活用に 関寸る研究一、日本建築学会中国・九州支部研究報告、第 10 号・ pp. 449-452、1996. 3

2) 朝比奈慶一ほか 4 名：九州地域における未利用エネルギー活用 に関する研究 その 6 建物床面積デー夕整備と開発計画および 各種処理実績に関するアンケート調查、平成 8 年度（第三回） 空気調和・衛生工学会九州支部学術研究発表会講演梗概集、 pp. 49-52、1996. 5

3）依田浩敏ほか 4 名 : 九州地域における未利用エネルギー活用に 関する研究 その 7 九州主要都市の商業地域における熱需要量 の推計、平成 8 年度（第三回）空気調和・衛生工学会九州支部 学術研究発表会講演梗概集、pp. 53-56、1996.5

4）北山広樹ほか 4 名 : 九州地域における末利用エネルギー活用に 関する研究その 8 九州主要都市における未利用エネルギー分 布と活用可能性、平成 8 年度 (第三回) 空気調和・衛生工学会 九州支部学術研究発表会講演梗概集、pp. 57-62、1996.5

5）近藤貴史ほか 5名：九州主要都市の商業地域における熱需要量 の推定 日本全国の地域冷暖房導入可能性に関寸る調查研究 そ の 17、日本建築学会大会学術講演梗概集、D・pp. 691-692、1996.9

6) 朝比奈慶一ほか 5 名 : 九州主要都市の未利用エネルギー分布と
賦存量 日本全国の地域冷暖房䆃入可能性に関寸る調查研究 そ の 18、日本建築学会大会学術講演梗概集、D·pp. 693-694、1996.9

7）植松史博ほか 5 名: 九州主要都市の既成市街地および新開発地 区の熱需要に関する研究、日本建築学会九州支部研究報告、第 36 号、pp. 393-396、1997. 3

8）朝比奈慶一ほか 4 名 : 九州主要都市における未利用エネルギー 活用可能地区の抽出と供給可能量、日本建築学会九州支部研究 報告、第 36 号、pp. $397-400 、 1997.3$

9) 北山広樹ほか 5 名: 九州地域における未利用エネルギー活用に 関する研究 その 9 既成市街地および開発地区における活用可 能性の検討、平成 9 年度（第四回）空気調和・衛生工学会九州 支部学術研究発表会講演梗概集、pp. 41-46、1997.5

10）依田浩敏ほか 4 名：九州地域における未利用エネルギー活用に 関する研究 その 10 九州主要都市における活用効果の試算、

平成 9 年度 (第四回) 空気調和・衛生工学会九州支部学術研究 発表会講演梗概集、pp. 47-52、1997.5

11）植松史博ほか 4 名: 九州主要都市の既成市街地および開発地区 における地域冷暖房導入可能性地区の抽出 日本全国の地域冷 暖房導入可能性に関する調查研究 その 22、日本建筑学会大会 学術講演梗概集、D・pp. 671-672、1997.9

12）依田浩敏ほか 4 名: 九州主要都市における未利用エネルギー活 用可能性地区の抽出と環境負荷低減勃果 日本全国の地域冷暖 房導入可能性に関寸る調査研究 その 23、日本建築学会大会学 術講演梗概集、D・pp. 673-674、1997.9

\section{参考文献}

13) 右田秀行ほか 4 名 : 福岡県における未利用エネルギー活用に関する研 究 (その5) 福岡市法定容積率 $400 \%$ 以上地域における建物属性と民 生用エネルギ一需要量の推定、日本建築学会研究報告九州支部、第 35 号・2、pp. 233-236、1995.3

14）（社）日本ガス協会 : 都市ガスによる末利用エネルギー活用シス テムについて(第 2 報)、1992.5

15）九州電力(株)：九州主要都市における未利用エネルギー賦存量 調查報告書、1992.3

16）下水熱利用促進研究会編 : 最新下水道 未利用エネルギー活用の 手引き地球にやさしいまちづくりをめざして、山海堂、1995. 12

17）福岡管区気象台 : 気象月報、1995. 1 12

18）尾島俊雄研究室 : 建築の光熱水原単位〔東京版]、早稲田大学 出版部、1995

19）宮村ほか：ヒートポンプ熱源としての河川水のポテンシャル評 価、日本建築学会北陸支部研究報告、1994.5

20）坂本ほか：名古屋市域における末利用エネルギーの活用による 省エネルギー効果の推計と評価（第 2 報 省エネルギー効果の 推計と評価）、空気調和·衛生工学会論文集、No. 58、pp. 111-118、 1995. 6

21）(財) 新エネルギー財団地域エネルギー委員会編 : 最新未利用エ ネルギー活用マニュアル、オーム社、1992.3

22）村上誠ほか 5 名:福岡市のエネルギー需要に関する調查解析 そ の 2 住宅、業務施設のエネルギー消費原単位、日本建築学会 大会学術講演梗概集、D・pp. 489-490、1993.9

23）陳超ほか 3 名: 福岡市と北九州市における各種建物のエネルギ 一消費特性に関する調查研究、日本建築学会計画系論文集、第 485 号、pp. 41-49、1996. 7

24）東京電力：電力設備、平成 6 年度

25) 東京電力 : 数表でみる東京電力、平成 8 年度

26）環境庁: 窒素酸化物総量規制マニュアル

27）環境庁：大気污染物質排出量総合調査、昭和 58 年

28）睘境庁：温暖化する地球、日本の取り組み

（1998年 7 月10日原稿受理，1998年 9 月18日採用決定） 